\title{
COMO ABANDONAR O NINHO ROMÂNTICO E VOAR: CONSTRUINDO UMA CULTURA IRONISTA DE DEFESA DOS DIREITOS FUNDAMENTAIS
}

\section{HOW TO LEAVE THE NEST AND FLY: BUILDING AN IRONIST CULTURE OF HUMAN RIGHTS}

\author{
Daniel Oitaven \\ Alessandra Scherma Schürig
}

\section{RESUMO}

O objetivo geral do artigo é questionar as bases paradigmáticas da cultura contemporânea de defesa dos direitos fundamentais mediante um cotejo entre a metafísica jurídica cômico-romântica do segundo Pós-Guerra e o ironismo cômico de Rorty. 0 núcleo do referencial teórico é a projeção, realizada por Robin West, dos mitos estéticos listados por Northrop Frye à teoria do direito, possibilitando a exploração da narrativa de "Os irmãos Karamázov" como alegoria para a angústia humana diante do caráter contingente das soluções jurídicas. Concluiu-se que a pós-modernidade demanda uma nova cultura jusfundamental, de caráter ironista (contextualista e falibilista), baseada em confiança e lealdade.

Palavras-chaves: Direitos fundamentais. Comédia romântica jurídica X ironismo. "Os irmãos Karamázov"

\section{ABSTRACT}

This article aims to assess the contemporary legal culture of basic rights by analyzing the conflict between post-World War II Era comic-romantic legal 
metaphysics and Rorty's comic ironism. The core of its theoretical framework is Robin West's effort to project Northrop Frye's aesthetical myths to Jurisprudence, a thesis which makes it possible to read "The Brothers Karamazov" as an allegory to human anguish concerning the contingent nature of legal answers. We concluded that the post-modern era demands a new culture of basic rights, which displays the traits of ironism (contextualism and fallibilism) and is based on trust and loyalty.

Keywords: Basic rights. Legal romantic comedy X ironism. "The Brothers Karamazov"

\section{INTRODUÇÃO}

0 presente trabalho tem como objetivo geral questionar a base paradigmática da cultura contemporânea de defesa dos direitos fundamentais mediante um cotejo entre a abordagem metafisica romântica típica do pensamento jurídico da segunda metade do século XX e abordagem ironista do direito sugerida por Richard Rorty.

A pergunta sobre a verdade e o alcance de essências é uma questão constante e tormentosa para o ser humano ao longo da história. A projeção desse questionamento metafísico ao âmbito do direito assumiu, após a Segunda Guerra Mundial, a condição de fundamento da cultura constitucional e da defesa dos direitos fundamentais. Ora, os anos após 1945 mostraram uma ascensão daquilo que Raimo Siltala (2011, p. 205) chamou de perspectiva jusnaturalista contemporânea, segundo a qual a justiça, ideal moral que alimenta o direito, depende estritamente da metafísica e da existência de uma "Verdade", a qual colocaria limites à capacidade do ser humano de convencionar padrões de comportamento. Em outras palavras, para essa tradição, se não existisse "A Verdade", tudo seria permitido, motivo pelo qual os direitos fundamentais precisariam ser caracterizados como objetiva e metafisicamente verdadeiros, sob pena de que os seres humanos incorressem novamente em erros semelhantes aos do período do Holocausto.

Com inspiração na teoria crítica literária, a presente investigação teórica, de caráter qualitativo e executada mediante o procedimento metodológico da análise de conteúdo bibliográfico - conectar essa 
tradição metafísica jusnaturalista a uma abordagem do direito classificada como romântica. Para tanto, buscou-se lastro em Robin West (1985), para quem toda teoria jurídica tem uma dimensão estética que pode e deve ser analisada com profundidade, visto que uma análise puramente filosófica de tais construções não é suficiente para dar conta de todos os seus pontos de vista relevantes.

O cerne do referencial teórico do escrito é justamente a tese de Robin West (1985) de que é possível o estabelecimento de uma relação entre quatro vertentes do pensamento jurídico e quatro "mitos estéticos". Para tanto, a autora inspira-se em Northrop Frye (2006), comumente considerado um dos maiores críticos literários do século XX. A lista de mitos estéticos nucleares de Frye tem quatro elementos. Dois desses elementos são métodos de narrativa contrastantes: o romance e a ironia. Os outros dois consistem em visões de mundo opostas: a cômica e a trágica.

A disputa entre adeptos do romantismo e do ironismo é bem mais profunda do que um simples debate sobre o significado do direito. De fato, a batalha entre eles é uma batalha entre, de um lado, a metáfora romântica e, de outro, o desafio irônico de expor todas as desilusões, ilusões e decepções dos românticos, bem como a correlata contingência das ideias e do direito (WEST, 1985, p. 148-9; 205). 0 método romântico pode ser conjugado com uma visão de mundo cômica (idealização romântica da realidade, de caráter apocalíptico, em que a civilização humana e as comunidades políticas, assim como as civilizações divinas, florescem) ou com uma visão de mundo trágica (em que se aspira a uma revolução que retire os membros da comunidade de um cenário presente infernal). Da mesma forma, o método irônico pode ser conjugado com uma visão de mundo cômica (em que se acredita na possibilidade de que o ser humano aprenda com os erros da história e, mesmo sem bases metafísicas, progrida socialmente em direção a uma comunidade moralmente melhor) ou com uma visão de mundo trágica (em que o irônico abraça o desalento com o irrefreável egoísmo humano, o qual configura toda autoridade e todo direito como violentos e arbitrários).

Neste artigo, destacaremos o embate entre: de um lado, a perspectiva cômico-romântica caracterizada pela adesão à metafísica, pela transcendentalização e pela identificação entre direito e moralidade 
típicos do jusnaturalismo contemporâneo e da correlata cultura de defesa dos direitos fundamentais; e, de outro, a abordagem cômico-irônica, em sua versão oferecida pelo ironista - sujeito consciente da contingência e da fragilidade de qualquer descrição de algo ou alguém como bom ou ruim - Richard Rorty (2007, p. 134), defensor de uma visão sobre o mundo (e o direito) antifundacionista, contextual, histórica e fundada na experiência ${ }^{12}$.

Conforme West demonstra, a tradição jurídica romântica dialoga com medos e anseios profundos da humanidade e busca responder ao profundo desejo humano por segurança e conforto. É justamente a respeito desses anseios insatisfeitos que brotam a angústia e o tormento de Ivan Karamázov, personagem do romance "Os Irmãos Karamázov", grande obra da literatura russa em que Fiódor Dostoiévski (2012) aborda a apreensão nutrida pelo ser humano diante da erosão das bases referenciais e metafisicas de comportamento e de integração social fornecidas pela religião. Assim como o modelo jusnaturalista contemporâneo, com receio de que se configure uma permissão universal para a livre realização de convenções normativas pelos seres humanos, defende que só haverá justiça na presença de fundamentos transcendentais; Ivan Karamázov, após perguntar-se a respeito de a crença na inexistência de Deus implicar que qualquer comportamento fosse permitido, sustenta ser indispensável que o controle social seja fundamentado em bases metafísico-religiosas. É diante da angústia e da sugestão de Ivan Karamázov que o ironismo de Richard Rorty, com seu modelo de moral relacional baseado nas noções de confiança e lealdade, e não em abstrações universalizantes, será apresentado como uma resposta contraposta, sem traços metafísicos, para a fundamentação da defesa dos direitos fundamentais, questão chave do constitucionalismo pós Segunda Guerra Mundial.

Diante do exposto, a investigação justifica-se socialmente pelo destaque assumido e pelas consequências produzidas pelo supracitado discurso metafísico no âmbito do pensamento e da prática jurídica da segunda metade do século XX em diante, notadamente no âmbito da atividade de interpretação constitucional desenvolvida pelos tribunais constitucionais. Ademais, a investigação justifica-se teoricamente: 
1) pelo caráter inovador do "insight" de West sobre a presença de aspectos emocionais e estéticos nas teorias do direito, aspecto raramente abordado no estado da arte brasileiro a respeito da crítica do modelo de discurso jurídico predominante entre os constitucionalistas brasileiros; e 2) pelo potencial ainda pouco explorado da narrativa de "Os irmãos Karamázov" como alegoria para a angústia vivida pelos juristas por conta da perspectiva de que o direito e suas respostas sejam meramente contingenciais.

\section{A TRADIÇÃO METAFÍSICA DOS DIREITOS FUNDAMENTAIS E A PERSPECTIVA CÔMICO-ROMÂNTICA SOBRE O DIREITO}

A verdade atormenta o ser humano e o ser humano corre em busca da verdade. Desde o nascedouro da filosofia, o que se buscou foi chegar à realidade e à verdade, desvendar as aparências e atravessar os véus. $\mathrm{A}$ busca pelo cumprimento de tal objetivo resultou em um sufocamento das contingências, bem como na construção de uma história contada ora na forma de um caminho para a iluminação, ora na forma de um afastamento paulatino em relação à mesma iluminação.

Por um longo período, algumas instituições - a Igreja, a família, o Estado, os sistemas econômicos - tiveram o papel de guardar "A Verdade". Essa função de guarda chegou até o direito. Se antes, com o direito canônico, a Igreja guardava o segredo sobre escolhas e liberdade, hoje teorias jurídicas defendem que a justiça, já tornada laica, ainda deve guardar para si o segredo "d’A Verdade" eterna. É assim que o direito se constrói sobre ideais transcendentais, alimentando a visão de direitos fundamentais imutáveis e universais.

Em um primeiro momento, a filosofia grega tentou compreender a natureza por meio de explicações que não recorressem aos mitos. Nessa esteira, surgiram os pré-socráticos, filósofos da natureza que se dedicaram a buscar o fundamento primeiro e originário, o princípio de todas coisas, denominado arché. Posteriormente, surge o modelo metafísico platônico, que tem como principal alicerce a existência de dois 
mundos: o mundo verdadeiro; e o mundo da mentira e das aparências. Ver o mundo real seria uma tarefa complexa a ser realizada com base em métodos pré-definidos. Os defensores de tal modelo metafísico defendem que a ignorância em relação ao conhecimento e à execução de tais métodos explicaria o fato de a maioria das pessoas viverem em um mundo de aparências, tomando sombras por realidade. Seria, pois, preciso sair das sombras para descobrir "A Verdade".

Os ideais metafísicos são a base do direito natural que defende um ideal de justiça universal fundado na razão humana. Esse movimento, no século XIX, sofre o impacto da ascensão dos modelos positivistas, os quais buscam afastar especulações metafísicas, mas ressurge com grande força após a Segunda Guerra Mundial. Tal ressurgimento se explica pela difusão da ideia de que o direito e as instituições jurídicas falharam drasticamente na defesa do ser humano, motivo pelo qual se deveria buscar uma alternativa ao positivismo que permitisse a renovação da esperança do surgimento de um mundo novo, mais tolerante.

Diante dessa perspectiva, desponta um novo momento do discurso de expansão da retórica dos direitos humanos, que, ao serem expressos em ordens positivas nacionais específicas, são denominados direitos fundamentais. Fomenta-se, paulatinamente, uma cultura de defesa dos direitos fundamentais que, em sua versão mais difundida, busca lastro em um ideal de justiça com bases metafísicas. 0 maior receio é o retorno do caos e da tragédia humana ocorrida na Segunda Guerra Mundial. A estratégia mais popular de enfrentamento de tais perigos na segunda metade do século XX consiste em uma abordagem transcendental, epistemologicamente absolutista e ontologicamente essencialista, a qual, segundo Raimo Siltala (2011, p. 205), configura uma espécie de direito de "Jusnaturalismo Contemporâneo" e tem uma significativa influência na construção dos direitos humanos constitucionais dos sistemas jurídicos ocidentais.

As noções de direitos humanos e direitos fundamentais constituem elemento nuclear do chamado constitucionalismo contemporâneo, típico dos países ocidentais, notadamente na tradição do civil law, no período pós-Segunda Guerra Mundial. Para Luis Roberto Barroso (2019, p. 3), a mencionada guerra marca a transição do modelo do "Estado Legislativo 
de Direito" - em que a Constituição era um documento político e suas normas não deviam ser aplicadas diretamente - para o "Estado Constitucional de Direito" - em que a Constituição se torna a força motriz do desenvolvimento de uma nova cultura jurídico-política, qual seja, a da defesa dos direitos humanos e dos direitos fundamentais.

A mencionada cultura de defesa configura os direitos humanos e os direitos fundamentais como os mais puros ideais de uma visão transcendental que reflete "A Verdade" pretensamente metafísica mediante apelos às noções de universalidade e racionalidade. A moral que fundamenta essa perspectiva metafísica sobre o direito não considera devidamente diferenças contextuais e nega a relevância das contingências. Trata-se de uma moral que se autocompreende como essencial e "Verdadeira”. Estabelecidas tais premissas, pode-se qualificar a narrativa constitucional de defesa dos direitos fundamentais construída com base no modelo jusnaturalista contemporâneo como uma abordagem romântica do direito. Senão, vejamos.

Robin West (1985, p. 152) estabelece uma distinção entre uma polaridade filosófica dominante no discurso jurídico. Essa polaridade se refere ao conflito entre as teorias do direito que o enxergam como um exercício da racionalidade e as que o concebem como o resultado do exercício do poder. Esse conflito tem como cerne as seguintes perguntas: 1) qual é a relação analítica entre o direito e a moralidade; e 2) metodologicamente, como se pode realizar uma distinção entre normas morais e normas jurídicas? As respostas orientadas pela razão têm caráter jusnaturalista e são construídas de modo análogo ao método narrativo romântico, enquanto as respostas centradas no poder da vontade humana podem ser aproximadas ao método narrativo irônico (WEST, 1985, p. 152)

West (1985, p. 152), ao conectar a tradição jusnaturalista ao método romântico de narrativa, sustenta que o jusnaturalismo costuma utilizar narrar uma busca pela moral ligada à "Verdade", encaminhando o intérprete para o papel de herói, virtuoso e triunfante, puro e íntegro, capaz de ofertar uma visão "neutra" do direito. Essa pretensa neutralidade consistiria na construção de um discurso que objetivaria representar " 0 que o direito realmente é”. 0 resultado dessa abordagem é uma espécie de incorporação da moralidade pelo direito. Em outras palavras, no modelo 
romântico, "a descoberta do direito requer a descoberta da verdadeira moralidade" (WEST, 1985, p. 152 - tradução nossa). Ademais, trata-se de um modelo tipicamente platônico: a idealizada coincidência entre direito e moral ocorre apenas no Paraíso ou no Apocalipse. A descoberta do direito, portanto, assim como a descoberta da verdade e da beleza, depende de uma transcendência em direção a um mundo ideal (WEST, 1985, p. 152).

No "romance constitucional", juízes heróis revelam a verdade para salvar um povo oprimido. Os heróis personificam as virtudes morais e, por meio da luta e do sofrimento, alcançam a vitória, pois, "ao fim da narrativa, o poder e o que é certo sempre convergem” (WEST, 1985, p. 158 - tradução nossa). Esse herói romântico, um verdadeiro "cavaleiro de armadura" é o responsável pela proteção do direito e pelo convencimento (ou pela derrota) dos que ainda não se submeteram à "Verdade".

Rorty (1994, p. 219) aponta que essa tradição cômico-romântica metafísica pressupõe uma espécie de descrença no próprio poder do humano e uma busca desesperada por um herói:

Esperamos desesperadamente que exista algo mais forte e poderoso, capaz de ferir o forte caso ele não se disponha a fazer isso- se não um Deus vingador, um proletariado vingador ou, pelo menos, um superego vingador ou, em último caso, a majestade ofendida de um tribunal da pura razão prática de Kant. A esperança aflita por um aliado poderoso e não contingente é, de acordo com Nietzsche, o ponto central comum ao platonismo, à insistência religiosa na onipotência divina e à filosofia moral kantiana.

0 anseio acima descrito resulta na tese jusnaturalista contemporânea de que constituições guardam "Uma Verdade Objetiva e Imutável", o que viabiliza a identificação do direito natural com um alto padrão moral, o qual, por sua vez, pode ser manejado para finalidades políticas (WEST, 1985, p. 167). Ora, como West (1985, p. 167) explica, o clamor pela virtude legitima o clamor pelo poder, como se pode depreender, exemplificativamente da peça de Shakespeare (2013) "Ricardo III", em que o rei Ricardo, após ser coroado e escolhido por Deus, não pode mais ser deposto, pois o sopro de homens mundanos não pode tocar o eleito do Senhor. Liga-se, pois, o governante virtuoso à vontade divina, assim 
como se proclama que ele e Deus estão acima de tudo. "The king can do no wrong", pois é apenas o receptáculo da pureza divina e o comandante dos demais "escolhidos" para defender a única "Verdade" 3 .

0 romantismo toca em profundos anseios humanos que, a rigor, consistem em desejos infantis: perfeição, cuidado, segurança, proteção e amor perfeito (WEST, 1985, p. 168). Tais desejos influenciam profundamente o direito e, apesar de nunca terem sido satisfeitos, seguem poderosos e influentes, tanto que a mera cogitação de uma cultura de direitos fundamentais que prescinda da metafísica resulta em uma grande angústia, tal qual a sentida por Ivan Karamázov ao imaginar um mundo em que Deus não existisse.

\section{DOSTOIÉVSKI E OS IRMÃOS KARAMAZÓV: QUEREIS IR PARA O MUNDO E ESTÁS INDO DE MÃOS VAZIAS.}

Saber se existem uma justiça e um direito sem bases metafísicas é parte da pergunta que Dostoiévski (2012) formulou ao escrever a obra magistral "Os irmãos Karamázov". Os irmãos mencionados no título do escrito são três: Alieksiêi, o mais jovem e bondoso, crente no amor e na Igreja; Ivan, o irmão do meio, descrente e angustiado; e Dímitri, o mais velho, dissoluto, fraco, confuso e apaixonado.

Alieksiêi estuda teologia e pretende tornar-se sacerdote. Por sua vez, Ivan, que cresceu como uma criança rejeitada pelo pai e órfão de mãe, tornou-se um jovem orgulhoso que revela aptidão extraordinária para os estudos. Com extrema dificuldade, Ivan consegue firmar-se como jornalista, retornando à casa paterna muitos anos depois para tratar de negócios com seu irmão mais velho, Dímitri, um bom homem, mas que está desesperado e afundado na podridão devido a uma vida de desejos desatados.

Ivan escreve um artigo no qual defende que, em uma sociedade cristã, a Igreja deveria tomar o poder do Estado. A motivação da personagem para tanto não é a fé no Cristianismo, e sim a crença de que a substituição da Igreja pelo Estado retiraria do ladrão, do ímpio, do desonesto a desculpa de dizer que seus atos ferem apenas o Estado. Ora, 
atos que ferissem a Igreja feririam o próprio Senhor e, consequentemente, resultariam na qualificação de seus praticantes em inimigos do Senhor, ou seja, adversários da própria base de uma civilização cristã. Os atos dos inimigos do Senhor, pois, seriam, nas palavras do stárietz Zossima, "atos horrendos que demandariam um castigo natural, o único real, o único que atemoriza e apazigua, que consiste em se ter consciência da própria consciência" (DOSTOIEVSKI, 2012, p. 96). Esse castigo seria o único meio de contenção do mal e só poderia ser aplicado por um poder metafísico, consubstanciado na Igreja.

Ivan acredita, como se pode depreender do parágrafo anterior, que a junção Igreja-Estado é a única forma de concretização da justiça e do alcance de um cenário de proteção social. Ao aliar a justiça aos conceitos divinos, aquele que atentasse contra as regras da sociedade atentaria contra as regras divinas, que, por sua vez, seriam inquestionáveis e, portanto, qualificadas de pronto como justas e corretas devido a sua origem sobre-humana. Tratar-se-ia, pois, de algo que não estava sujeito aos erros e desacertos dos seres humanos, algo que não era contingente. Em suma, a verdadeira justiça só poderia vir de Deus e, consequentemente, a metafísica seria um pressuposto da justiça.

Ivan, angustiado, explica suas aflições ao conversar com Zossima, protetor de Alieksiêi ${ }^{4}$. Ele deseja um mundo bom e correto, mas enxerga todas as dificuldades existentes. Ivan chora pelas criancinhas que sofrem tragédias em toda a sua inocência. Por que Deus, se é tão justo, deixa criancinhas sofrerem? Ivan conclui que, se o preço a pagar para que haja justiça no mundo é o amor de Deus, é melhor que a humanidade pague esse preço. Ivan defende as verdades eternas da Igreja porque acredita que este caminho metafísico é o único meio de a humanidade não se estilhaçar irremediavelmente.

Alieksiêi, apesar de todo o seu amor pela humanidade, não compreende a angústia de seu irmão Ivan. Alieksiêi, para quem as coisas são simples, diz para Ivan: olhe os prados, olhe o sol, olhe as flores. Para o irmão caçula, a grandeza e a justiça divina estão em tudo, bastando olhar o mundo para que se percebá que Deus e a justiça são puro amor. 0 sofrimento das criancinhas, para Alieksiêi, tem um sentido maior, ofertado 
por Deus, e, consequentemente, tem um potencial redentor, razão pela qual não deve ser motivo de revolta ou indignação.

Por sua vez, Zossima, mestre de Alieksiêi, apresenta um entendimento estranhamente profundo no decorrer da discussão. ${ }^{5}$. Para ele, o segredo "não estava no amor contemplativo que anseia por uma proeza imediata, que possa ser rapidamente realizada e que todos vejam" (DOSTOIEVSKI, 2012, p. 92), e sim no amor ativo, composto de trabalho árduo, educação e autodomínio por parte de quem o pratica. É preciso trabalhar duro e conter os desejos, não bastando contemplar as flores e o céu. Não se deve fechar os olhos para a dor, a fome, as guerras e os erros, e sim procurar amar seus próximos de forma ativa e incansável justamente por conta desses problemas e das dores correlatas.

Zossima sabe que "o amor ativo, comparado ao contemplativo, é algo cruel e apavorante” (DOSTOIEVSKI, 2012, p. 92), bem como tem consciência da dificuldade de sua ideia conseguir aceitação. Sua tese não é aceita por Ivan, que zomba da ideia de amor ativo. Ivan considera que não existe solidariedade, visto não haver nada que determine que os seres humanos se amem e se respeitem.

Toda a virtude provém do medo de um castigo sobre-humano. Apenas o medo do severo castigo que, certamente, seria dado por um ser superior caso suas leis fossem quebradas poderia manter a sociedade coesa. 0 medo era necessário para que as pessoas não errassem, não matassem, não se destruíssem. Sem o medo de estarem a infringir um ideal, as pessoas seguiriam violentando, matando, roubando.

Se o único meio de estancar o sofrimento era fazer com que os seres humanos acreditassem que eram almas imortais - o que acabaria com o sofrimento, resultando em redenção, compaixão e solidariedade - era preciso que a Igreja restaurasse seu poder. Para Ivan, ao se destruir a fé dos seres humanos na imortalidade, será neles exaurido, de imediato, não apenas o amor, "mas também toda a força para viver, e não haverá mais nada amoral, tudo será permitido, até a antropofagia. Ao se descrer do eterno, fatalmente o homem converteria em lei o egoísmo" (DOSTOIEVSKI, 2012, p. 110).

Ivan Karamázov é atormentado por não entender os "desígnios divinos". Ele tem medo de sua própria liberdade e não sabe até onde 
pode ir. Sem que haja um castigo claro e definido, como ele e os demais podem ter a segurança de caminhar? Ele exclama:

... sei apenas que o sofrimento existe, que não há culpados, que todas as coisas decorrem umas das outras de forma direta e simples, que tudo transcorre e se nivela- ora, isso é apenas uma asneira euclidiana, e eu mesmo sei disso, e não posso concordar com viver segundo essa asneira! Pouco se me dá se não há culpados e eu sei disso; preciso do castigo, senão vou acabar me destruindo... (DOSTOIEVSKI, 2012, p. 338).

Ivan lamenta ser impossível viver sem crer. Para ele, dizer que as coisas simplesmente decorrem umas das outras não seria um princípio suficiente para se erigir uma vida. Uma vida precisa ser inspirada por "algo mais". É necessário um encantamento. É necessária a metafísica.

Delineia-se, então, uma luta não evidente. A luta não se dá entre enxergar e não enxergar erros, desvios e perturbações, ou seja, contingências. 0 que se tem é um embate entre duas posições que enxergam as contingências de forma clara, mas divergem na forma de lidar com ela. De um lado, Alieksiêi começa, como discípulo de Zossima, defendendo a religião e acaba falando em afeto, humanidade e Cristo - Não em Deus, Senhor Único, mas em Cristo, deus encarnado, o ser humano que sofre por escolher. Do outro lado, Ivan parte de uma posição de rejeição à metafísica e à busca pela objetividade cientifica e acaba defendendo que a única coisa que pode salvar a humanidade é a Igreja (e não Cristo), com seu poderio metafísico.

Para defender sua posição, Ivan conta uma história sobre a vinda de Jesus Cristo ao mundo. Nessa narrativa, Jesus Cristo deseja aparecer ao povo que $\mathrm{O}$ amava e escolhe, para tanto, a época da Inquisição, em Sevilha. Jesus aparece em silêncio, mas o povo que $\mathrm{O}$ ama não deixa de reconhecêlo e, consequentemente, de chorar de emoção. Em certo momento, Jesus ressuscita uma pequenina morta e isso é o bastante para que Grande Cardeal Inquisidor apareça e o arraste de imediato, acorrentado pelos pés e mãos. Ao interrogar Jesus Cristo, o Grande Cardeal explica que Ele não tem o direito de contar mais nada sobre o mundo para os seres humanos. Ora, as pessoas torturaram-se com a liberdade de escolher durante quinze séculos, o que só mudou quando elas se tornaram convictas de que eram 
livres, depositando, contudo, essa liberdade, docilmente, aos pés da Santa Igreja. O grande cardeal, então, pergunta: "O homem foi feito rebelde, por acaso os rebeldes podem ser felizes?"6 (DOSTOIEVSKI, 2012, p. 349).

Para o Grande Inquisidor, o ser humano considera a tranquilidade mais cara do que o livre arbítrio. Não existe nada pior para o ser humano do que a sufocante e angustiante liberdade de escolher. Liberdade é angústia. Jesus Cristo, ao querer dar liberdade aos seres humanos, "os sobrecarregava de tormentos dizendo que ao invés da firme lei antiga, do Antigo Testamento, agora o homem deveria resolver de coração livre o que é o bem e o que é o mal, tendo diante de si a sua própria imagem como guia" (DOSTOIEVSKI, 2012, p. 353). Jesus Cristo não prometia aos seres humanos nada mais do que os deixar livres para escolher. Isso é insuportável: a liberdade é um fardo e uma dor. Como reverbera o Grande Inquisidor, a liberdade não é um bem:

Quereis ir para o mundo e estás indo de mãos vazias, levando aos homens alguma promessa de liberdade que eles, em sua simplicidade e em sua imoderação natural sequer podem compreender, da qual têm medo e pavor, porquanto para o homem e para a sociedade humana nunca houve nada mais insuportável do que a liberdade! (DOSTOIEVSKI, 2012, p. 351)

Segundo o Grande Inquisidor, o ser humano não quer liberdade, e sim segurança e paz, o que só pode obter exatamente por meio da liberdade. É preciso ofertar aos seres humanos verdades irrefutáveis, absolutas e incontestáveis. Viver em liberdade seria viver em intranquilidade, blasfêmia, desordem e infelicidade - a sina dos seres humanos livres. Por tal razão, a Igreja decide intervir, como o Grande Inquisidor relata ao afirmar o seguinte: "faz muito tempo que já não estamos contigo, mas com 〈ele〉, já se vão oito séculos”. (DOSTOIEVSKI, 2012, p. 356). “Ele” não era o que se pode pensar em um primeiro momento. "Ele" era o grande Estado teocrático, o qual tinha Roma no centro e subjugava até os imperadores.

Para o Grande Inquisidor, o segredo da existência humana não está no viver, mas na finalidade do viver. Sem uma sólida noção dessa finalidade, o ser humano prefere destruir-se. Porém, não seria cada ser humano quem deveria definir sua própria razão de ser, e sim a 
Igreja, instituição que ofertaria a verdadeira finalidade do viver aos seres humanos.

Em síntese, os seres humanos viveriam uma mentira, mas morreriam serenamente. 0 segredo dessa mentira seria bem guardado pela Igreja, que, para que os seres humanos fossem felizes, tomaria para si o fardo da mentira e do embuste. A Igreja, unindo-se ao Estado, esconderia a inexistência da "Verdade", de modo que os seres humanos, confiando na justiça divina (a qual, por meio das leis de Deus, inspiraria as leis dos seres humanos) e protegidos da liberdade (e da correlata responsabilidade de escolher), vivessem em paz e em segurança

A posição de Ivan proclama que, apesar de clamar por liberdade, o ser humano deseja segurança e solidez. Essa é a premissa que, ao ser transposta para o direito, responde, em moldes românticos - no sentido assumido por Robin West - não apenas a apelos científicos, mas a profundos anseios, medos e esperanças humanas. Alimenta-se, assim, a perspectiva de que os direitos fundamentais devem ser defendidos com base em um ideal metafísico, o qual sufoca as contingências e despreza tanto a história quanto a liberdade.

\section{NÃO ESTAMOS DE MÃOS VAZIAS: A CORAGEM DA RENÚNCIA ÀS CERTEZAS METAFÍSICAS.}

No contexto da pós-modernidade, em que a "liberdade é o nosso destino, uma sorte de que não se pode desejar o afastamento e que não se vai embora por mais intensamente que possamos desviar dela os nossos olhos" (BAUMAN, 1997, p. 251), chega-se à conclusão de que as alternativas disponíveis ao ser humano diante da liberdade são encará-la ou padecer. Uma projeção dessa ideia ao âmbito do direito permite que se afirme o seguinte: ou o ser humano procura um modelo de sustentação dos direitos fundamentais que não seja regido pela metafísica e não negue as contingências, ou a própria cultura dos direitos fundamentais estará fadada à queda.

0 mundo está em um processo de incertização, o que conduz a uma crescente fragmentação (BAUMAN, 1997, p. 251). Não haverá descanso, 
pois a liberdade traz a angústia sobre a possibilidade de errar. Mas essa é uma condição a ser enfrentada, sob pena de queda em uma armadilha: a tentação de acreditar que um cavaleiro de armadura, como receptáculo da "Verdade", conhece e detém a receita infalível que fornecerá soluções mágicas. Como Bauman (1992, p. 252) alerta, receitas infalíveis são, para a liberdade, a responsabilidade e a liberdade responsável, o que a água é para o fogo. Contudo, não há liberdade sem angústia, motivo pelo qual poucos escolhem encarar a liberdade.

Uma justiça que se proclama detentora do segredo da "Verdade" nega a liberdade. Como alternativa, propõe-se a preferência pela liberdade e pelo falibilismo, o que significa enxergar a verdade e a justiça com letras minúsculas, símbolos visuais de sua pluralidade. E essa proposição conduz à seguinte pergunta: "seria a infixidez da situação atrativa o bastante para prevalecer sobre a angústia da incerteza?" (BAUMAN, 1997, p. 22).

Diante das exigências da pós-modernidade, é preciso achar um modo de jogar com as cartas que são dadas em uma época extremamente mutável e desprovida das antigas metanarrativas. Ora, a modernidade estava vinculada a um tempo-espaço rijo, sólido, durável, o qual pretendia controlar a experiência humana passo a passo. 0 homem moderno, pois, sabia para onde caminhar. Diferentemente, na pós-modernidade, as contingências, por tanto tempo sufocadas na história, foram liberadas. No mundo pós-moderno, vive-se com a consciência de que não há solidez em um mundo indomável: “a única arte que há é saber como jogar o jogo com as cartas que se tem e fazer o máximo com elas" (BAUMAN, 1997, p. 112).

Em linha semelhante, Teubner (2005, p. 20) enxerga a dissolução da certeza não meramente em níveis individuais, mas sociais, o que ele expressa por meio do conceito de policontexturalidade, "uma das mais desconcertantes experiências do nosso tempo". A policontexturalidade consiste na pluralidade de autodescrições da sociedade, o que resulta na formação de diversas racionalidades parciais - por exemplo, a econômica (código binário "ter/não-ter"), a política (código binário "poder/não poder") a jurídica (código binário "lícito/ilícito") a artística (código binário "belo/feio") e a religiosa (código binário transcendente/ imanente). Em um cenário de "pluralidade de códigos-diferença 
orientadores da comunicação nos diversos campos sociais", as diversas racionalidades entram em confronto, cada uma delas com pretensão de universalidade (NEVES, 2009, p. 23). Diante da policontexturalidade, é necessária uma nova forma de disputa sobre a justiça e a moral. Essa nova forma, segundo Teubner $(2005$, p. 20) precisa não mais se ater à troca entre atores individuais ou às abstrações kantianas, e sim encarar a questão da fragmentação da sociedade e dos múltiplos conceitos sobre justiça e bem viver.

A policontexturalidade atinge a compreensão romântica dos direitos fundamentais, visto que estes, a despeito de reconhecerem a pluralidade do ambiente do sistema jurídico, não conseguem cumprir o papel de fechar as possibilidades interpretativas com base "em concepções teóricas que buscam responder às demandas de justificação racional derivadas" da dogmática jurídica tradicional sobre a matéria (CARNEIRO, 2018, p. 136). Em outras palavras, a perspectiva jusnaturalista contemporânea sobre os direitos fundamentais não é compatível com a pretensão de que o sistema jurídico reduza a complexidade dos eventos correlatos à matéria mediante um bloqueio de determinadas possibilidades de produção de sentido.

0 enfrentamento da fragilidade das bases metafísicas da cultura jusnaturalista contemporânea de defesa dos direitos fundamentais pressupõe que se perceba o seu vínculo com uma abordagem jusnaturalista, de caráter cômico-romântico, do direito, a qual acredita na

abstração e na possibilidade de buscar essências não reveladas. É possível abordar os direitos fundamentais sem, como fazem os cômicoromânticos, sustentar uma identidade entre o direito e a moral? Será que a única maneira de fazê-lo é incorrer em uma atitude cética diante da impossibilidade de metarrelatos, ou seja, um niilismo trágico-irônico?

0 método narrativo irônico, contraponto à abordagem romântica, assume como lema o compromisso empírico de nunca esperar que algo ou alguém seja mais do que aparenta ser. Em outras palavras, não se deve buscar uma abstração supostamente escondida atrás do fenômeno. Não há nada ali. Não há essência a ser revelada ou descoberta. Por conta de tal premissa, o herói do movimento irônico terá sua vida ordenada com 
base na experiência, e não em uma suposta verdade escondida sob o empírico ou em promessas de recompensas futuras (WEST, 1985, p. 169).

Via de regra, o método irônico tenta mostrar as muitas falhas do modelo romântico, mostrando a realidade por trás de convenções morais, religiosas e sociais. Para um irônico, a história do romantismo e de sua projeção ao direito, ou seja, a crença em um direito natural - é "uma história de enganos: esse inferno burocrático, atomista, alienado em vivemos, ao final, não é o melhor mundo que somos capazes de ter" (WEST, 1985, p. 179 - tradução nossa).

Além de satirizar o romantismo, a abordagem irônica narra o direito de modo alternativo: em vez de assumir como referência a metafísica abstrata, escolhe a análise de experiências, da história e de contextos humanos. Ao negar a metafisica, certo é que o método irônico pode caminhar entre extremos, indo desde uma desconfiança cômica e saudável (uma espécie de realismo razoável) em relação a narrativas românticas até o extremo trágico de acreditar que o direito é meramente uma vontade de poder desprovida de componente moral (WEST, 1985, p. 156).

0 apelo de Ivan Karamazov é motivado justamente pelos perigos do extremo trágico do método irônico. Ora, Ivan teme uma visão de mundo trágico-niilista, defensora da tese de que não há nenhuma inclinação dos seres humanos à construção de um mundo liberal e livre em que eles possam gozar das semelhanças e diferenças entre si, e sim uma tendência humana à construção de um mundo que resulte na autodestruição da espécie (WEST, 1985, p. 180). É por isso que Ivan acha relevante que se defenda a existência de Deus: se Ele não existisse, sobraria apenas a autodestruição ${ }^{7}$.

Contudo, há também quem defenda uma postura irônica mais comedida. Ora, é intrínseca à abordagem irônica do direito a premissa de que os eventos contingentes que condicionam a experiência abarcam as atividades legiferante e jurisdicional, ou seja, eventos produzidos por seres humanos, e não por princípios neutros abstratos. Se tais eventos dependem de seres humanos e referem-se a questões práticas - algumas, inclusive, comezinhas, como a quantidade de processos, a escassez de servidores e as consequências das decisões - falhas, 
acertos e, principalmente, mudanças acontecerão, mas nada disso tem relação com "cavaleiros de armadura" em busca da verdade. Tais são os pressupostos assumidos pelo filósofo ironista Richard Rorty, defensor de uma perspectiva intermediária, a qual não incorre nos excessos dos extremistas românticos - "somos filhos desobedientes de um Deus amoroso" e "os seres humanos diferem de outros tipos de animal por terem dignidade em lugar de mero valor" tampouco nos dos extremistas trágico-irônicos - "seres humanos são simplesmente veículos de genes egoístas ou erupções da vontade de poder” (RORTY, 1994, p. 205).

Se é verdade que todo irônico nega a identificação entre o direito que é e o que deveria ser, a distinção entre a vinculação de um irônico à visão de mundo cômica ou à visão de mundo trágica consiste justamente na adoção de um otimismo razoável ou um pessimismo desolador sobre a relação entre o direito e a moral. Ora, o cômico-irônico, como é o caso de Rorty, acredita que a experiência histórica mostra o caminho para o progresso, enquanto o trágico-irônico entende que ela revela o caráter nefasto, irremediavelmente arbitrário e violento, do ser humano. De tal maneira, as ambas as perspectivas podem identificar o direito positivo como fruto de uma convenção, mas a perspectiva narrativa trágico-irônica não tem esperança em qualquer tipo de progresso, enquanto o ironista está sempre vigilante sobre degradações do ser humano realizadas em nome do que está positivado.

O caminho intermediário traçado por Rorty, em vez de assumir generalizações sobre a natureza humana como as dos extremistas cômico-românticos e a dos radicais trágico-irônicos, prefere o particular ao universal, o contextual ao abstrato. A ideia do narrador cômico-irônico é expor as desilusões românticas resultantes das convicções jusnaturalistas, preparando o terreno para ofertar um novo modo de ver o direito. Na perspectiva irônica, o que é relevante é estar aberto às contingências e entender que qualquer visão que defina a história como uma marcha para a iluminação ou para o desespero não procede, pois eventos são contingentes. As crenças que permanecem, atravessando as contingências, são apenas crenças que se mostraram úteis para a preservação da humanidade ao longo da história e que fornecem explicações plausíveis ao nosso impulso incessante de 
encontrar um sentido para os mais diversos eventos. Nesse modelo, portanto, crenças que atravessam a história não são amostras de uma natureza humana ou de um conhecimento metafísico, tampouco são eternas ou garantem o sucesso.

0 romantismo tece uma tapeçaria que busca esconder as contingências, "encobrir a ilegível confusão do transe humano com uma limpa e inteligível aparência de sentido" (BAUMAN, 1997, p. 148). Porém, o caos e a luz não são previsíveis. Não é possível prever utopias ou distopias: que se olhe, então, para o passado, em busca de uma inspiração para apostas futuras. $\mathrm{O}$ apelo do modelo irônico de narrar o direito está justamente na insistência realística da distinção não-fundacionista entre o que é e o que deveria ser, a qual contribui para o progresso em direção aos sonhos compartilhados pela humanidade (WEST, 1985, p. 182). Para um cômico-irônico, é preciso alimentar a resistência ao impulso de romantização daquilo que é, ou seja, do presente. Em vez de buscar a transcendência em direção à verdade abstrata, deve-se tentar entender melhor o passado, a história, e aprender normativamente com ela.

Adotado o modo irônico de narrar o direito, deve-se pensar em uma moralidade que não subscreva a universalidade e a transcendentalidade, e sim que se baseie na experiência histórica. Nesse sentido, Rorty (2005, p. 107) sugere que dilemas morais devem ser tomados como conflitos entre centros de gravidade de narrativa, o que significa enfatizar o papel indispensável das relações humanas na formação da moral, em vez de buscar racionalmente uma suposta moral universal. Trata-se, pois, de uma concepção de moral como "nossa lealdade a outros seres humanos que lutam juntos contra a escuridão, e não nossa esperança de fazer as coisas certas" (FISH, 1991, p. 215 - tradução nossa).

Uma moral baseada na lealdade pode servir como base para a defesa da Constituição e dos direitos fundamentais em um contexto de fragmentação de sentidos e policontexturalidade. Para Rorty, ao se perscrutar a humanidade, percebe-se que o conflito recorrente entre seres humanos é "entre lealdades conflitantes, e não um conflito entre uma noção de justiça racional de um lado e uma lealdade afetiva e irracional do outro lado" (RORTY, 2005, p. 100). Quando alguém está envolvido em um conflito interior a respeito da escolha entre lutar na 
guerra ou deixar seus pais desamparados, há, propriamente, um conflito entre uma lealdade a um grupo maior (a comunidade política) e uma lealdade a um grupo menor (a família), o que configura tal dilema como relacional (RORTY, 2005, p. 104). Nesse cenário, pode-se imaginar uma moralidade que começaria com o estabelecimento de uma relação de confiança recíproca entre os membros de um grupo e seria continuamente ampliada, de modo a abarcar cada vez mais pessoas - o que significa, no âmbito jurídico, que uma moral que alimente o direito e a defesa de direitos fundamentais ao modo ironista deverá buscar expandir a lealdade para grupos cada vez maiores.

Um ironista abre mão da visão romântica e aceita a fragmentação, expurgando os metarrelatos. Sobra para ele, contudo, a existência, que deve ser contemplada mediante uma razão comunicativa e dialógica, e não por um modelo de racionalidade solipsista. 0 caminho do meio rortyano, ao rejeitar o monologismo e a metafísica, abraça a possibilidade de que os aprendizados com a experiência histórica (e os erros cometidos) fundamentem o surgimento de vínculos de solidariedade que contribuam para a humanidade evitar a produção de novos regimes terríveis, como o nazismo ou o apartheid. Ora, diante da queda do império da transcendência, surge com força a responsabilidade, seja coletiva, seja individual. Se não existe destino, os escudos transcendentais têm que dar lugar a escolhas responsáveis. Nesse contexto, os sentimentos de lealdade e a sua expansão dependem da percepção das semelhanças e diferenças entre os membros do gênero humano, o que pressupõe uma substituição da responsabilidade perante um padrão não humano, de caráter metafísico, pela responsabilidade perante outros seres humanos. Trata-se, pois, de "baixar nossas vistas, do incondicional acima de nós, para a comunidade em torno de nós” (RORTY in CRISÓSTOMO, 2003, p. 256).

A moral, para o ironista, não é uma questão de revelação metafísica, e sim algo que se adquire por meio da educação, de relatos, de regras, de ordens, de estórias ficcionais e de estórias não ficcionais. Trata-se, pois, de uma construção diuturna, exaustiva e necessária ${ }^{8}$. 0 que se pode fazer é encarar o caráter contingente da experiência humana com responsabilidade, expandindo-se a educação para a solidariedade e a lealdade, pois "a obrigação moral é questão de condicionamento, e 
não de insight" (RORTY, 1997, p. 153). Se é verdade que a construção de uma sociedade precisa abarcar tanto o sofrimento quanto o afeto sentimentos aos quais os seres humanos são suscetíveis - está correto o poeta Whitman (1964, p. 9-10) ao afirmar que essa construção deve ser inspirada na solidariedade e na empatia9:

\author{
A Base de Toda Metafísica \\ Tendo estudado antigos e modernos, \\ sistemas dos gregos e dos germânicos, \\ tendo estudado e situado Kant, Fichte, Schelling e Hegel, \\ situado a doutrina de Platão, \\ e Sócrates superior a Platão, \\ e outros ainda superiores a Sócrates \\ buscando pesquisar e situar, \\ tendo estudado bastante o divino Cristo, \\ eu vejo hoje reminiscências daqueles \\ sistemas grego e germânico, \\ deparo todas as filosofias, \\ templos e dogmas cristãos encontro, \\ e mesmo sem chegar a Sócrates eu vejo \\ com absoluta clareza, \\ e sem chegar até o divino Cristo, \\ eu vejo o puro amor do homem por seu camarada, \\ a atração de um amigo pelo amigo, \\ de uma mulher pelo marido e vice-versa \\ quando bem conjugados, \\ de filhos pelos pais, \\ de uma cidade por outra, \\ de uma terra por outra.
}

É preciso expandir lentamente a noção de que a dor alheia importa. Existem comunidades que conseguem adotar essa noção de forma firme, outras não. Ao longo do tempo, esse sentimento foi rejeitado ou incorporado em legislações, mas nunca foi uma questão de revelação ou de abraçar um absoluto. Em uma sociedade pós-moderna, fragmentada e 
sem metanarrativas de suporte, o que é viável é um direcionamento dos esforços para a expansão da lealdade por meio da educação contínua, e não um apelo à racionalidade de bases metafísicas.

$\mathrm{O}$ caminho irônico da razoabilidade, sem reagir ao abandono da metafísica mediante um apelo a extremos niilistas, defende que a moral a respaldar a compreensão dos direitos fundamentais seja relacional, tendo a lealdade, e não abstrações, como referência. De tal maneira, o discurso dos direitos fundamentais poderá se beneficiar do afastamento em relação à cultura metafísico-romântica ao substituir a ideia de que defender direitos fundamentais é uma obrigação racional moral por uma postura de valorização da confiança. Trata-se, pois, de deixar de lado a esperança de que, finalmente, o cavaleiro, com sua armadura brilhante, possa nos salvar - nas palavras de Rorty (1994, p. 219), de deixar de "esperar que o forte volte seus olhinhos vorazes para o sofrimento do fraco, que ele abra devagar seu pequeno coração empedernido" (RORTY, 1994, p. 219). Desistamos, pois, da pureza dos ideias da cavalaria em favor de objetivos simples, comuns, falhos, contingentes e humanos.

\section{CONSIDERAÇÕES FINAIS}

Na luta entre segurança e liberdade - enfrentada individualmente por cada um e transplantada para as instituições - o direito sempre optou pela segurança como forma de manutenção da ordem e, por isso, acatou uma abordagem romantizada, que, apostando na metafísica, pretende descobrir o que "O Direito Realmente É". Nesse modelo, a busca pela verdade nunca era efetivamente satisfeita, mas continuava a ser empreendida, visto ser responsiva às angústias humanas, ao profundo medo humano de abandonar o ninho da certeza e da segurança em nome da liberdade e da aceitação da falta de um destino. Contudo, as expectativas conectadas a essa abordagem romântica estão atreladas a um tempo que não retornará. 0 mundo atual é o mundo da liberdade e das contingências.

Se, à la Bauman, a pós-modernidade evidenciou que o ganho de alguma coisa habitualmente vem acompanhado da perda de outra 
coisa, algo decisivamente perdido pelos seres humanos no contexto contemporâneo foi a segurança. A liberdade, atualmente, aparenta estar em todos os cantos, enquanto a segurança e a ordem parecem estar escondidas. Diante dessa constatação, o mais acertado não é correr em desespero de volta à ilusória segurança, e sim lidar com a indefinição da existência.

Se é certo que uma enorme força atinge a cultura de defesa dos direitos fundamentais nessa época de fragmentação de sentidos classificada como pós-modernidade, definir tal força como destrutiva ou tão somente modificadora depende do modo de encarar a questão. Certo é que a cultura de defesa dos direitos fundamentais foi construída sobre bases fundacionistas e a fragmentação de sentidos causa grande dificuldade para a defesa de ideais abstratos e universalizantes no mundo contemporâneo.

Diante da fragmentação pós-moderna, percebe-se a impossibilidade de fundamentação da defesa dos direitos fundamentais em uma visão metafisica e romântica. Compreendido e superado o anseio por conforto e segurança que provém desse berço metafísico, caberá aos defensores dos direitos fundamentais, em vez de negar a policontexturalidade, compreendê-la e aceitá-la. Essa tarefa pressupõe que discurso sobre os direitos fundamentais substitua sua base tradicional - a moralidade metafísica - por um modelo contextualista e falibilista que, por um lado, subscreva uma conjugação entre lealdade e confiança e, por outro, rejeite o niilismo e o ceticismo.

De fato, quando, por força do Iluminismo, o respaldo do respeito a outro ser humano deixou de estar nos sentimentos e tornou-se inspirado na razão, a moral transformou-se em uma obrigação autônoma, não mais se conectando à percepção da dor e da humilhação alheias. Contudo, a metafisica falhou perante os desafios pós-modernos à cultura constitucional, que precisa responder não apenas às crescentes críticas à universalidade, mas também ao fomento de polaridades e diferenças. Sugere-se aqui que esses desafios não podem ser resolvidos pela via dos apelos a uma igualdade e uma razão universais, e sim mediante a aceitação da diferença, da angústia, da finitude e do sofrimento comum a todos os seres humanos. Faz-se, pois, salutar uma espécie de educação 
sentimental que vise à aceitação das diferenças e ao diálogo com tais diferenças - contexto em que o potencial da literatura e das artes pode cumprir papel decisivo, visto contribuir para a expansão do sentimento de solidariedade e a ampliação dos níveis da lealdade.

A resposta para a angústia dos que padecem pela falta da metafísica é uma resposta frágil, contextual, temporária, contingente, mas profundamente humana. Seus aparentes defeitos são suas maiores virtudes. É essa resposta que pode servir como inspiração para a construção de uma cultura de defesa dos direitos fundamentais que enfrente com coragem os desafios pós-modernos ao modelo constitucionalista tradicional.

\section{NOTAS}

1 A semelhança entre a abordagem ironista desenvolvida por Rorty e o mito estético da ironia descrito por Northrop Frye também foi percebida por João Carlos Biella (2008), que se inspirou em ambas as perspectivas para analisar a poesia de José Paulo Paes. Essa percepção demonstra ser viável qualificar o ironismo de Rorty, de acordo com a tipologia dos modelos de narrativa sobre o direito formulada por Robin West, como um modelo narrativo irônico-cômico.

2 Rorty (2007, p. 134) define o ironista "como alguém que satisfaz três condições: (1) tem dúvidas radicais e contínuas sobre o vocabulário final que usa atualmente por ter sido marcado por outros vocabulários, vocabulários tomados como finais por pessoas ou livros que ele deparou; (2) percebe que a argumentação enunciada em seu vocabulário atual não consegue corroborar nem desfazer estas dúvidas; (3) na medida que filosofa sua situação, essa pessoa não acha que seu vocabulário esteja mais próximo da realidade do que outros, que esteja em contato com uma força que não seja ele mesmo. Os ironistas que se inclinam a filosofar vêem a escolha entre os vocabulários como uma escolha que não é feita dentro de um metavocabulário neutro e universal, nem tampouco por uma tentativa de lutar para superar as aparências e chegar ao real, mas simplesmente como jogar o novo contra o velho".

3 É relevante ressaltar que a tradição romântica jusnaturalista pode ser caracterizada como ambígua, visto que uma razão comum para que seja defendida é o seu potencial para combater não apenas a anarquia, mas também, à la Antígona, um poder tirânico. Trata-se, pois, de uma perspectiva metafísica que pode, mediante a manipulação dos medos e angústias enfrentados pelos seres humanos, servir tanto a fins políticos conservadores e/ou reacionários (como costuma ocorrer nos modelos cômico-românticos de abordagem do direito) como a finalidades políticas revolucionárias (traço típico dos modelos trágico-românticos de abordagem do direito) (WEST, 1985, p. 168). Manteremos, contudo, o recorte temático anunciado na introdução, de modo a concentrar nossa investigação no embate entre a comédia romântica jusfundamental contemporânea, de traços metafísicos, e a comédia irônica rortyana.

4 A personagem Zossima é um velho sacerdote peregrino detentor de profunda sabedoria.

5 Essas são ideias muito próximas às palavras professadas por Liêvin, alter ego de Tolstói em Anna Kariênina. É curioso observar que Tolstói, logo após concluir essa obra, passou por uma profunda crise existencial e, em seguida, fundou sua própria religião, rompendo com a Igreja Ortodoxa Russa e criando uma fé baseada no Sermão da Montanha. Camus (2010) afirma que abandonar a metafísica é, inicialmente, um grito de angústia, mas, na medida em que o ser humano aceita a insegurança, há liberdade e alívio - e muito dessa constatação está na 
jornada empreendida por Tolstói. Também é curioso observar que, como Ray Monk (1995, p. 129) relata, Wittgenstein teve acesso à obra religiosa de Tolstói enquanto lutava na Primeira Guerra Mundial e disse que foi isso que o manteve vivo. Como se vê, a literatura tem muito a ensinar à filosofia e, mais ainda, ao direito.

6 Os rebeldes podem ser felizes ou é melhor que eles depositem suas esperanças aos pés de um herói virtuoso e proclamem, sempre que possível, sua fidelidade aos ideais de virtude desse grande herói? Essa é uma pergunta pertinente ainda hoje.

7 É interessante destacar que Posner, um defensor do pragmatismo jurídico e antigo adepto da Análise Econômica do Direito, deplorada por West (1985, p. 157) como uma tradição do extremo irônico, se queixa de que a moral não é epistemicamente forte para servir de base ao direito (RORTY, 2007, p. 921). Nessa sua queixa sobre a falta de firmes bases epistêmicas para a moral está presente a metafísica, o que se coaduna com a tese de Rorty de que do outro lado do arco íris da metafísica sempre será encontrado um cético.

8 Nada impede que o abismo aconteça de novo, a não ser o cuidado constante e uma educação aprofundada que busque a empatia. Essa educação, para o pensamento ironista, não deve vir apenas da filosofia. É preciso que a etnografia, a reportagem, os documentários e os romances façam os seus papéis.

9 Cascudo (1992, p. 9), um dos tradutores de poemas de Whitman para o português, corrobora essa interpretação sobre os escritos do poeta: "Qual será a base de toda Metafísica? [...] Walt Whitman crê que seja o instinto do solidarismo humano. 0 instinto afetuoso é o que nos aproxima da compreensão, da assimilação, do entendimento. Deste fundamento sobem as cidades ideais de religiões e sistemas filosóficos, cabriolando no infinito. [...] A piedade, a caridade, a compaixão [...] são manifestações imediatas do solidarismo".

\section{REFERÊNCIAS}

BARROSO, Luis Roberto. Jurisdição Constitucional: a tênue fronteira entre direito e a política. 2014. Migalhas. Disponível em: https://www.migalhas.com.br/ dePeso/16,MI194782,51045-Jurisdicao+Constitucional+A+tenue+fronteira+e ntre+o+Direito+e+a. Acesso em: ago. 2019.

BAUMAN, Zygmunt. 0 mal-estar na pós modernidade. Rio de Janeiro: Zahar, 1997.

BIELLA, João Carlos. Um ironismo como outro qualquer: a ironia na poesia de José Paulo Paes. São Paulo: UNESP, 2008.

CAMUS, Albert. 0 mito de Sísifo. Rio de Janeiro: Best, 2010.

CARNEIRO, Wálber Araújo. Hermenêutica Jurídica Heterorreflexiva. São Leopoldo: Unisinos, 2009.

CARNEIRO, Wálber Araújo. Os direitos fundamentais da Constituição e os fundamentos da Constiuição de direitos: reformulações paradigmáticas na 
sociedade complexa e global. Revista de Direito da Mackenzie, v. 12, 2018, p. $129-165$.

CASCUDO, Luís da Câmara. Três poemas de Walt Whitman. Mossoró: Coleção Mossoroense, 1992.

DOSTOIEVSKI, Fiodor. 2012. Os Irmãos Karamázov. São Paulo: Editora 34, 2012.

FRYE, Northrop. Anatomy of criticism: four essays. Toronto: University of Toronto Press, 2006.

MONK, Ray. Wittgenstein: o dever do gênio. São Paulo: Companhia das Letras, 1995.

NEVES, Marcelo. Transconstitucionalismo. São Paulo: Martins Fontes, 2009.

RORTY, Richard. Contingência, ironia e solidariedade. São Paulo: Martins Fontes, 2007a.

RORTY, Richard. Dewey and Posner on Pragmatism and Moral Progress. John Dewey Lecture at The University of Chicago Law School, v. 74, 2007b, p. 915-927.

RORTY, Richard. Grandiosidade universalista, profundidade romântica, finitude humanista. In: CRISÓSTOMO, José. Filosofia, Racionalidade e Democracia: os debates Rorty \& Habermas. São Paulo : UNESP, 2003, p. 247 e ss.

RORTY, Richard. Objetivismo, relativismo e verdade. Rio de Janeiro: Relume Dumará, 1997.

RORTY, Richard. Pragmatismo e Política. São Paulo: Martins Fontes, 2005.

RORTY, Richard. Verdade e progresso. Barcelona: Paidós Ibérica S.A, 1994.

SCHÜRIG, Alessandra Scherma. Se a metafísica não existe, tudo é permitido? um diálogo entre a verdade e a contingência diante da pós-modernidade. Dissertação de Mestrado - (Faculdade de Direito da UFBa), 2019.

SHAKESPEARE, William. Ricardo III. São Paulo: Saraiva, 2013. 
SILTALA, Raimo. Law, Truth and Reason: a treatise on legal argumentation. Helsinki: Springer, 2011.

TEUBNER, Gunther. "Justiça autosubversiva: fórmula de contingência ou de transcendência do direito?" Revista Eletrônica do Curso de Direito - Puc Minas Serro, 2011.

WEST, Robin. Jurisprudence as Narrative: An Aesthetic Analysis of Modern Legal Theory. New York University Law Review, v. 60 , n. 178, 1985, p. 145-211.

Recebido em: 01-09-2019

Aprovado em: 09-12-2019

\section{Daniel Oitaven}

Doutor em Direito Público pela Universidade Federal da Bahia; doutor em Ciências Sociais pela UFBA; mestre em Direito pela Faculdade de Direito da UFBA, especialista em Teoria e Filosofia do direito pela PUC Minas, especialista em Direito Tributário pela PUC-SP/COGEAE; professor de Hermenêutica Jurídica, Filosofia do Direito e Argumentação Jurídica da Faculdade Baiana de Direito, Professor Efetivo Adjunto "A" de Teoria do Direito, Filosofia do Direito, Hermenêutica Jurídica, Lógica e Argumentação Jurídica, Sociologia do Direito, História do Direito e Instituições de Direito Público e Privado da Faculdade de Direito da UFBA; professor permanente do Programa de Pós-Graduação (mestrado e doutorado) em Direito da UFBA.E-mail: danieloitaven@hotmail.com

\section{Alessandra Scherma Schürig}

Doutoranda em Direito pela Universidade Federal da Bahia (UFBA); mestre em Direito pela Universidade Federal da Bahia; com concentração na área de Direitos Fundamentais e Justiça; especialista em Direito Processual Civil pela Universidade Federal da Bahia; especialista em Direito Público pela Universidade Católica do Salvador. E-mail: alessandra.schurig@hotmail.com

Universidade Federal da Bahia

Av. Adhemar de Barros, s/no - Ondina, Salvador - BA, 40170-110 
